\title{
ANALISIS KESEHATAN HUTAN REPONG DAMAR BERDASARKAN INDIKATOR PRODUKTIVITAS
}

\author{
REPONG DAMAR FOREST HEALTH ANALYSIS BASED ON PRODUCTIVITY \\ INDICATORS \\ Oleh
}

Cici Doria ${ }^{1)}$, Rahmat Safe'i ${ }^{2)}$, Dian Iswandaru ${ }^{3)}$, Hari Kaskoyo ${ }^{4)}$

${ }^{1)}$ Mahasiswa Jurusan Kehutanan Fakultas Pertanian Universitas Lampung

${ }^{2,3,4)}$ Dosen Jurusan Kehutanan Fakultas Pertanian Universitas Lampung

Jl. Prof. Dr. Ir. Sumantri Brojonegoro, Gedung Meneng, Bandar Lampung 35145

Email : rahmat.safei@fp.unila.ac.id

Diterima : 4 Maret $2021 \quad$ Disetujui: 23 Maret 2021

\section{Abstrak}

Repong damar oleh masyarakat sekitar hutan dijadikan sebagai penunjang perekonomian guna menambah penghasilan untuk mencukupi kebutuhan hidup, karena repong damar dapat menciptakan rangkaian kegiatan ekonomi yang lain seperti pemanenan, pengangkutan dari kebun ke desa, penyimpanan, sortasi, dan pengangkutan ke para pedagang besar di pasar Krui. Penelitian ini bertujuan untuk mengetahui nilai parameter indikator produktivitas dan status kesehatan hutan repong di Pekon Pahmungan, Pesisir Barat. Untuk mencapai hal tersebut, tahapan-tahapannya antara lain: penentuan jumlah kalster plot, pembuatan klaster plot FHM di repong damar, pengumpulan data dan analisis data produktivitas dan nilai akhir kesehatan hutan. Hasil dari penelitian ini menunjukkan hutan repong damar di Pekon Pahmungan Kabupaten Pesisir Barat memiliki nilai kesehatan hutan yang sedang berdasarkan indikator produktivitas. Hal tersebut berpengaruh terhadap pengelolaan hutan rakyat kedepannya dengan fungsi utama hutan yaitu produksi. Dengan diketahuinya nilai produktivitas dan kondisi kesehatan hutan, maka pengelola dapat membuat keputusan pengelolaan hutan yang tepat.

Kata kunci : repong damar, indikator produktivitas, LBDs, kesehatan hutan.

\begin{abstract}
.
Repong damar by the community around the forest is used as an economic support in order to increase income to meet their daily needs, because repong damar can create a series of other economic activities such as harvesting, transporting from gardens to villages, storing, sorting, and trasnporting to wholesalers in the Krui market. This study aims to determine the value of the indicator parameters of productivity and health status of the Repong forest in Pekon Pahmungan, Pesisir Barat. To get this goals, the stages include: determining the number of cluster plots, establishing FHM cluster plots in repong damar, collecting and analyzing data on productivity and final forest health values. The results of this study indicate that the repong damar forest in Pekon Pahmungan, Pesisir Barat Regency has a moderate forest health value based on productivity indicators. This affects the management of community forests in the future with the main function of the forest, namely production. By knowing the value of productivity and forest health conditions, managers can make appropriate forest management decisions..
\end{abstract}

Keywords: repong damar, productivity indicators, LBDs, forest health.

DOI:10.30598/jhppk.2021.5.1.14 


\section{PENDAHULUAN}

Repong damar adalah salah satu sistem pengelolaan sumberdaya alam yang dikelola langsung oleh masyarakat Pesisir Barat, Lampung (Nainggolan, 2011). Repong damar dijadikan sebagai penunjang perekonomian dengan rangkaian kegiatan ekonomi seperti pemanenan dan pengangkutan yang dilakukan oleh pemilik kebun dan keluarga, pengangkutan dari kebun ke desa yang Secara turun temurun masyarakat mengelola repong damar dengan memanfaatkan getah damar mata kucing (Shorea javanica). Pasalnya getah damar biasa digunakan sebagai bahan mendempul perahu, untuk penerangan, dupa, bahan pewarna, perekat dan obat. Getah damar telah

Sistem penanaman dalam repong damar adalah agroforestri yang terdiri dari berbagai jenis tanaman yang hidup secara produktif, dilestarikan dan dimanfaatkan secara langsung oleh masyarakat seperti durian, duku, petai, jengkol, melinjo, manggis, kelapa, kayu manis, kakao, rotan, dan sebagainya. Selain jenis tanamannya yang melimpah, repong damar juga memiliki fauna yang beragam, seperti siamang, monyet ekor panjang, cecah, lutung kelabu, dan lainnya

Berdasarkan segi ekologi, hutan sehat merupakan hutan yang dapat menampakkan hubungan sosial yang sebanding antar semua dilakukan oleh pekerja upahan, penyimpanan, sortasi, serta pengangkutan ke para pedagang besar yang dilakukan oleh pedagang pengumpul (De Foresta dkk., 2000). Sehingga, masyarakat yang bukan petani damar atau yang tidak memiliki kebun masih bisa mengambil keuntungan dari budidaya damar.

dikenal sejak lama sebagai salah satu potensi ekonomi yang tinggi. Perdagangan damar telah berlangsung sejak awal abad ke10 di Cina dan negara-negara di Asia Tenggara, kemudian berkembang ke Amerika dan Eropa awal abad ke-19 (Cusson, 2013).

(Harianto dkk., 2016). Beragamnya fauna di repong damar dikarenakan adanya tanaman pepohonan yang menyediakan sumberdaya pakan, tempat berkembang biak dan untuk berlindung (Dewi dkk., 2017). Hutan dapat dicap sehat jika suatu hutan tersebut masih bisa memuat atau memenuhi tiga fungsi terpenting yang sudah ditetapkan, fungsi produksi, fungsi lindung dan fungsi konservasi (Nuhamara dkk., 2001).

unsur yang terdapat di hutan (Safe'i dan Tsani, 2016). Produktivitas merupakan laju pertumbuhan dari suatu pohon atau tegakan 
dalam periode waktu tertentu atau saat ini. Produktivitas dapat diketahui dengan melakukan pengukuran pertumbuhan pohon (Safe'i dkk., 2019). Pertumbuhan pohon dihitung berdasarkan luas bidang dasar (LBDs) (Safe'i dan Tsani, 2017). LBDs

Hingga saat ini, perhatian yang serius tentang pentingnya kesadaran akan kesehatan hutan dalam pengelolaan hutan yang lestari di provinsi lampung masih sangat kurang (Safe'i dkk., 2019). Kondisi kesehatan hutan

Berdasarkan uraian diatas, pengelola repong damar perlu mengetahui kondisi ekosistem repong damar melalui kacamata kesehatan hutan, mengingat kesehatan hutan adalah salah satu tujuan didalam pengelolaan

\section{METODE PENELITIAN}

Penelitian ini berlokasi di hutan Repong Damar Pekon Pahmungan, Kecamatan Pesisir Tengah, Kabuapaten menggambarkan tingkat pertumbuhan sesaat atau produktivitas pohon dari waktu ke waktu. Data yang diperlukan untuk menghitung LBDs yaitu dengan mengukur diameter pohon (Kuswandi, 2017).

repong damar sangat berpengaruh terhadap keberlanjutan ekosistemnya. Tahapan yang bisa dilakukan untuk menjamin manfaat dan fungsi hutan adalah dengan cara pengukuran kesehatan hutan (Safe'i dkk., 2021).

hutan yang lestari (Handoko dkk., 2015). Penelitian ini perlu dilakukan untuk mengenal keadaan kesehatan hutan repong damar dengan menggunakan indikator kesehatan hutan yaitu produktivita

Pesisir Barat yang dilaksanakan pada bulan Februari tahun 2021. Peta lokasi penelitian dapat dilihat pada Gambar 1.

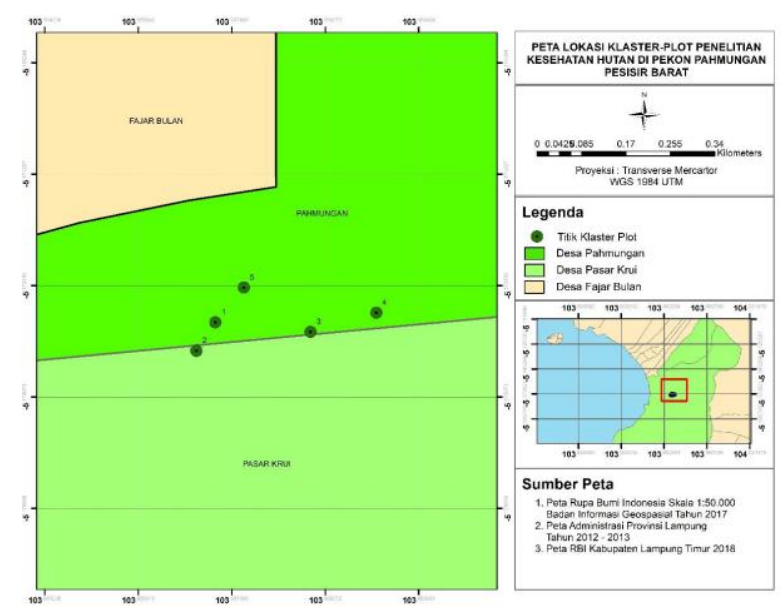

Gambar 1. Peta lokasi penelitian 
Alat yang digunakan dalam penelitian yaitu: buku panduan praktikum Kesehatan Hutan (Safe'i dan Tsani, 2016), tally sheet, pita meter $(150 \mathrm{~cm})$, meteran, hagameter, paku pines, label plastik, kompas, kamera digital, spidol permanen dan Global Positioning System (GPS). Metode yang digunakan dalam pemantauan kesehatan hutan ini adalah metode FHM (Forest Health Monitoring) (Safe'i, 2015). Objek penelitian yaitu lima klaster plot

1) Memiliki annular plot berupa lingkaran; jari-jari 17,95 m, subplot; jari-jari 7,32 m dan mikroplot; jari-jari 2,07 m.

2) Titik pusat subplot 1 (satu) adalah titik pusat bagi keseluruhan plot, titik pusat subplot 2 (dua) terletak pada arah $0^{\circ}$ atau $360^{\circ}$ dari titik pusat subplot 1 (satu), titik pusat subplot 3 (tiga) terletak pada arah $120^{\circ}$ dari titik pusat subplot 1 (satu) dan titik pusat subplot 4 (empat) terletak pada arah $240^{\circ}$ dari titik pusat subplot 1 (satu), dengan masing-masing jarak antara titik pusat subplot yaitu 36,6 m.
FHM yang berisi tegakan damar. FHM merupakan metode pemantauan kesehatan hutan yang diintroduksikan oleh USDA untuk memonitor. Pemantauan kesehatan hutan dilakukan terhadap indikator ekologis yaitu produktivitas. Gambar 2. merupakan kerangka klaster plot FHM kesehatan hutan dalam repong damar. Dalam pembuatan klaster plot FHM, harus diperhatikan beberapa kriterianya yaitu:

3) Klaster plot tersusun atas 4 annular plot, subplot serta mikroplot dan titik contoh tanah

4) Titik pusat subplot 1 (satu) merupakan titik pusat bagi keseluruhan plot, titik pusat subplot 2 (dua) terletak pada arah $0^{\circ}$ atau $360^{\circ}$ dari titik pusat subplot 1 (satu), titik pusat subplot 3 (tiga) terletak pada arah $120^{\circ}$ dari titik pusat subplot 1 (satu) dan titik pusat subplot 4 (empat) terletak pada arah $240^{\circ}$ dari titik pusat subplot 1 (satu), dengan masing-masing jarak antara titik pusat subplot adalah $36,6 \mathrm{~m}$. 


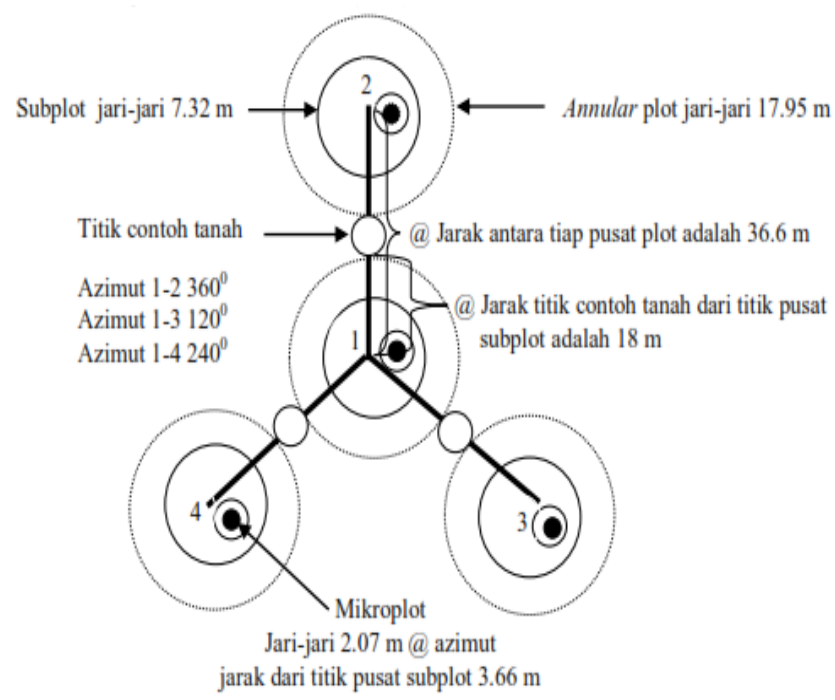

Gambar 2. Desain klaster plot Forest Health Monitoring (FHM)

Data lapangan dikumpulkan dan pertambahan dari jumlah serta dimensi diperoleh dengan cara pengukuran parameter pohon, yaitu diameter dan tinggi yang produktivitas. Parameter yang digunakan pada penelitian ini adalah pertumbuhan pohon (LBDs) yang datanya dapat diperoleh melalui pengukuran diameter. Diameter batang diukur $1,3 \mathrm{~m}$ di atas permukaan tanah. Teknik pengukuran pertumbuhan pohon atau produktivitas dilakukan terhadap tegakan damar yang berada di dalam setiap plot klaster. Pertumbuhan pohon merupakan terdapat pada suatu pohon (Davis and Jhonson 1987 dalam Safe'i dan Tsani., 2016). Pertumbuhan pohon dihitung sebagai pertumbuhan luas bidang dasar (LBDs). Parameter LBDs dipilih karena merupakan parameter yang mudah dalam pengukurannya dan memiliki tingkat konsistensi yang tinggi (Cline 1995). Berikut merupakan rumus dari LBDs:

$$
\text { LBDs }=1 / 4 \times \pi \mathrm{xd}^{2}
$$

Keterangan :

$$
\begin{aligned}
\text { LBDs }= & \text { luas bidang dasar individu } \\
& \text { pohon }\left(\mathrm{m}^{2}\right) \\
\mathrm{d} & =\text { diameter batang }(1,3 \text { meter } \\
& \text { dari dasar pohon }) \\
\pi & = \\
& \text { konstanta }(3,14)
\end{aligned}
$$

Penilaian kesehatan hutan pada repong damar di Pekon Pahmungan diperoleh dari nilai akhir kondisi kesehatan hutan damar tersebut. Penilaian ini bertujuan untuk berdasarkan indikator dari produktivitas. Untuk mendapatkan nilai akhir kesehatan hutan dapat menggunakan rumus sebagai menentukan kondisi kesehatan hutan saat ini

$$
\mathrm{NKHr}=\mathrm{NT} \times \mathrm{NS}
$$


Keterangan :

$$
\begin{aligned}
\text { NKHr }= & \text { nilai akhir kondisi kesehatan } \\
& \text { Hutan repong damar } \\
\text { NT } & \text { nilai tertimbang parameter } \\
& \text { dari indikator produktivitas } \\
\text { NS } & \text { nilai skor parameter dari } \\
& \text { indikator produktivitas }
\end{aligned}
$$

NKH adalah nilai akhir dari kondisi kesehatan hutan, NT yaitu nilai tertimbang parameter dari setiap indikator kesehatan hutan, dan NS adalah nilai skor parameter dari setiap nilai skor 1-10. Sedangkan nilai tertimbang (NT) diperoleh dari Analytic Networking Process (ANP) (Safe'i dkk., 2016). Karena hanya menggunakan satu indikator, ANP tidak digunakan. Nilai NT untuk satu indikator yaitu

\section{HASIL DAN PEMBAHASAN}

Keberhasilan hutan rakyat agroforestri yang dijalankan oleh masyarakat setempat secara tradisional dan sangat baik perlu mendapat perhatian dalam pengelolaan lahan hutan. Repong Damar Pekon Pahmungan adalah salah satu contoh hutan rakyat yang masih terjaga kelestariannya. Masyarakat lokal biasa menyebut Repong damar dengan istilah kebun damar. Herawati (2012) menjelaskan bahwa selain tegakan damar, repong damar juga memiliki berbagai jenis

Hal ini senada dengan pemahaman bahwa salah satu manfaat hutan rakyat yang dapat dirasakan oleh masyarakat secara langsung yaitu meningkatkan produktivitas lahan, sumber pendapatan dan bahan baku industri (Safe'i dkk., 2017). Faktor yang menentukan kuantitas dan kualitas kayu atau indikator kesehatan hutan (Safe'i dkk., 2018). Nilai skor didapat dari perubahan terhadap nilai parameter setiap klaster plot dengan rentang

1 (satu). Namun, pada penelitian ini tidak menggunakan ANP dalam penentuan nilai tertimbang. Hal tersebut dikarenakan tidak ada indikator lain untuk dilakukannya pembandingan berpasangan.

tanaman lainnya seperti duku (Lansium domesticum), durian (Durio zibethinus), cempedak (Artocarpus champeden), manggis (Garcinia mangostana), kayu-kayuan, obatobatan dan semak belukar. Hasil hutan dari Repong Damar berupa getah damar yang menjadi sumber pendapatan penting bagi masyarakat untuk memenuhi kebutuhan hidup sehari-hari, terkhusus untuk biaya pendidikan anak-anak (Lensari dan Yuningsih, 2017).

pohon salah satunya yaitu kesehatan hutan. Status kesehatan hutan menggunakan indikator ekologis yang terukur merupakan salah satu cara pemantauan kesehatan hutan (Putra, 2004). Cermin dari tingkat kesehatan dan keberhasilan pengelolaan hutan rakyat repong damar dilihat dari rendah tingginya 
produktivitas dalam hutan tersebut (Putra, 2004).

Tingkat produktivitas repong damar wajib diperhatikan agar fungsi produksi hutan rakyat terpenuhi (Safe'i, 2017). Produktivitas merupakan laju pertumbuhan dari suatu tegakan dalam periode waktu tertentu. Tingkat produktivitas tegakan damar dapat diketahui dengan melakukan pengukuran pertumbuhan pohon (Safe'i dkk., 2019). Menurut Riyanto dan Pamungkas (2010), pola pertumbuhan diameter serta titik optimum pertumbuhan diameter dapat menggunakan kurva laju pertumbuhan pohon. Pertumbuhan pohon dihitung sebagai luas bidang dasar (LBDs) (Safe'i dkk., 2013). LBDs dapat dihitung dengan mengetahui diameter pohon. Pertumbuhan diameter pohon adalah parameter pertumbuhan pohon yang memiliki tingkat konsistensi yang tinggi dan mudah dalam pengukurannya (Philip, 1994). Pengukuran parameter indikator Kesehatan hutan dilakukan pada klaster plot dalam sub plot. Hasil penilaian LBDs pada setiap klaster plot dapat dalam Tabel 1.

Tabel 1. Nilai LBDs pada setiap klaster plot

\begin{tabular}{|c|c|}
\hline Klaster plot & LBDs $\left(\mathrm{m}^{2}\right)$ \\
\hline 1 & 0,280 \\
\hline 2 & 0,200 \\
\hline 3 & 0,280 \\
\hline 4 & 0,260 \\
\hline 5 & 0,400 \\
\hline
\end{tabular}

Sumber: diolah dari data lapangan

Besaran nilai LBDs merupakan penilaian pohon per hektar yang dapat dilihat pada skor parameter pertumbuhan tegakan. Di (Tabel 2).

setiap klaster plot diketahui nilai rata-rata

Tabel 2. Nilai skoring pada parameter LBDs

\begin{tabular}{ccc}
\hline Skor & LBDs \\
\hline 1 & 0,2 & 0,219 \\
2 & 0,220 & 0,239 \\
3 & 0,240 & 0,259 \\
4 & 0,260 & 0,279 \\
5 & 0,280 & 0,299 \\
6 & 0,300 & 0,319 \\
7 & 0,320 & 0,339 \\
8 & 0,340 & 0,359 \\
9 & 0,360 & 0,379 \\
10 & 0,380 & 0,4 \\
\hline
\end{tabular}

Sumber: Diperoleh dari dat lapangan 
Interval 1-10 untuk nilai skoring. Nilai dimulai dari nilai terkecil sampai dengan yang terbesar. Tingkat kesehatan hutan tinggi karena nilai skor yang tinggi sebaliknya jika tingkat kesehatan hutan semakin rendah artinya nilai skor juga rendah. Besaran nilai LBDs rata-rata pohon per hektar merupakan cara untuk mengetahui skoring kondisi pertumbuhan pohon (Safe'i, 2017). Interval 1-10 tersebut memberikan tingkatan pada setiap nilai yang ada terhadap masingmasing klaster plot ukur yang telah diperoleh sebelumnya. Tabel 3 merupakan besaran nilai skor parameter LBDs untuk mengetahui nilai ambang batas status kesehatan hutan.

Tabel 3. Nilai ambang batas status kesehatan hutan berdasarkan indikator produktivitas

\begin{tabular}{ccc}
\hline No & Kategor & Kelas \\
& $\mathrm{i}$ & Nilai \\
\hline 1 & Baik & $1,96-2,80$ \\
2 & Sedang & $1,12-1,95$ \\
3 & Jelek & $0,28-1,11$ \\
\hline
\end{tabular}

Sumber: Diperoleh dari data lapangan

Nilai kondisi kesehatan hutan Repong Damar pada setiap klaster plot (Tabel 4).

Tabel 4. Nilai akhir status Kesehatan hutan berdasarkan indikator produktivitas

\begin{tabular}{ccc}
\hline Klaster & NKH & Status \\
\hline 1 & 2,02 & Sedang \\
2 & 0,36 & Jelek \\
3 & 1,48 & Sedang \\
4 & 1,20 & Jelek \\
5 & 3,57 & Baik \\
\hline
\end{tabular}

Sumber: Diperoleh dari data lapangan

Tabel 4 menjelaskan bahwa hutan repong damar yang dikelola langsung oleh Kelompok Tani Seandanan memiliki hasil status kondisi hutan pada kategori baik satu klaster-plot (klaster plot 5), kategori sedang dua klaster plot yaitu klaster plot 1 dan 3 . Sedangkan klaster plot 3 dan 4 masuk kategori buruk. Sehingga, nilai rata-rata status kondisi kesehatan hutan Kelompok
Tani Seandanan berada pada kategori sedang. Pengelolaan repong damar dilakukan dengan tujuan agar menghasilkan HHK (Hasil Hutan Kayu) dan HHBK (Hasil Hutan Bukan Kayu), contohnya buah, rota, serta daun untuk mencukupi kebutuhan hidup sehari-hari tanpa merusak ekologis hutan. Karenanya, kondisi tegakan pohon pada suatu area harus terpelihara secara baik, agar fungsi produksi 
hutan terpenuhi dengan cara mengetahui kondisi tingkat produktivitas pohon tersebut (Safe'i, 2017). Hal ini dikarenakan cermin

Parameter yang digunakan untuk meningkatkan produktivitas pohon yaitu laju pertumbuhan pohon (pengukuran luas bidang dasar) serta volume pohon. Menurut Riyanto (2009), pertumbuhan pohon adalah pertambahan ukuran suatu sistem organik dalam jangka waktu tertentu. Luas bidang

Berdasarkan Tabel 1, pertumbuhan tertinggi terjadi pada klaster plot lima dengan nilai $0,400 \mathrm{~m}^{2}$. Sedangkan pertumbuhan terendah yaitu $0,200 \mathrm{~m}^{2}$ yang terdapat pada klaster plot dua. Hal ini menunjukkan bahwa produktivitas pohon di klaster plot lima tinggi dan di klaster plot dua rendah (Safe'i dkk., 2019). Rata-rata dari nilai setiap parameter indikator kesehatan hutan ini sedang. Dengan demikian, dapat diketahui bahwa semakin

Dengan begitu, pertumbuhan pohon yang digambarkan dengan LBDs bisa dipakai untuk menjelaskan produktivitas saat ini (Cline, 1995). Indiaktor produktivitas akan menjadi dasar penilaian kesehatan hutan selain indikator keanekaragaman hayati, vitalitas dan kualitas tapak. Perhitungan nilai akhir kondisi kesehatan hutan repong damar adalah cara penilaian status kondisi kesehatan hutan

Untuk mewakili luasan hutan repong damar dari keberhasilan pengelolaan hutan terlihat dari tinggi rendahnya produktivitas (Putra, 2004).

dasar menggambarkan tingkat pertumbuhan sesaat atau produktivitas pohon dari waktu ke waktu dengan cara mengukur diameter pohon (Kuswandi, 2017). LBDs adalah penampang melintang dari diameter setinggi dada (1,3 $\mathrm{m}$ dari permukaan tanah) (Sahid, 2009).

bertambahnya umur pohon maka pertumbuhan pohon akan semakin tinggi. Besarnya tingkat pertumbuhan akan berkolerasi terhadap kesehatan repong damar. Perbedaan nilai LBDs tersebut disebabkan tinggi serta diameter, dan tingkat pertumbuhan pohon lebih tinggi yang dapat memicu pertumbuhan yang lebih tinggi begitupun sebaliknya (Ansori dkk., 2020).

repong damar. Hasil skoring terhadap nilai LBDs yang diperoleh merupakan nilai akhir kondisi kesehatan hutan (Safe'i dkk., 2021). Nilai tersebut diperoleh hasil dari pengurangan nilai maksimal terhadap nilai minimal dan kemudian dibagi dengan tiga (kategori yang dipakai). Dari ketiga kategori yang ada maka akan diketahui kondisi kesehatan hutan repong damar.

maka dibuat lima klaster plot yang memiliki 
kondisi yang berbeda-beda tergantung kepada besarnya diameter dan umur pohon yang diukur. Berdasarkan Tabel 4, dari lima klaster plot yang dibuat terdapat satu klaster plot masuk kategori baik, kategori sedang yaitu dua klaster plot, dan kategori jelek pada dua klaster plot. Klaster plot 1 dan 3 memiliki

Tinggi rendahnya nilai skor dan nilai tertimbang dari setiap parameter dapat mempengaruhi baik buruknya nilai akhir status kondisi kesehatan hutan. Tingginya nilai akhir kondisi kesehatan hutan disebabkan oleh besarnya nilai skor dan nilai tertimbang dari setiap parameter (Safe'i, 2015). Jenis kerusakan pohon merupakan bentuk gangguan pertumbuhan tanaman yang gejalanya dapat dilihat dari bentuk, ukuran, warna, dan tekstur (Safe'i dkk., 2020). Besarnya nilai kerusakan pohon serta kecilnya nilai $\mathrm{pH}$ tanah juga dapat mempengaruhi status kondisi kesehatan hutan yang tidak baik bahkan buruk. Tegakan pohon di dalam hutan

Nilai Kesehatan hutan di Repong Damar adalah sedang (cukup baik), hal ini disebabkan tempat tumbuh serta syarat tumbuh lainnya memenuhi untuk ditanami oleh pohon damar (Shorea javanica). Dari hasil analisis terhadap lima klaster plot, perlu dilakukan perlakuan intensif terhadap klaster yang masuk dalam kategori sedang dan buruk. Klaster plot dengan kondisi kesehatan hutan yang baik pun tidak lepas dari pemeliharaan. Segala bentuk kondisi kesehatan hutan yang buruk dikarenakan keanekaragaman pohonnya yang rendah. Menurunnya keragaman fungsi ekologi disebabkan karena nilai keanekaragaman jenis pohonnya semakin rendah. Hal ini mengakibatkan tingkat stabilitas ekologi menurun.

harus sehat supaya kondisi kesehatan hutan juga. Berbeda dengan tegakan pohon yang tidak sehat yang akan ditandai dengan kualitas tapak yang tidak subur yang menyebabkan pertumbuhan tegakan kurang optimal. Kondisi kesehatan hutan repong damar di Pekon Pahmungan Kecamatan Pesisir Tengah Kabupaten Pesisir Barat masuk dalam kategori sedang. Kondisi tersebut disebabkan oleh tingginya nilai LBDs pada masingmasing klaster plot. Semakin tinggi nilai skor maka tingkat kesehatan hutan akan semakin tinggi pula, sebaliknya jika tingkat kesehatan hutan semakin rendah artinya nilai skor juga rendah (Safe,i dkk., 2015).

pengelolaan harus berdasarkan prinsip keberlanjutan dari fungsi hutan. Prinsip tersebut akan memberi dampak yang baik terhadap kesehatan hutan khususnya ditinjau dari produktivitas tanamannya. Dalam hal ini, indikator produktivitas dalam kesehatan hutan sangat penting mengingat hutan rakyat memiliki fungsi produksi. Kesehatan hutan rakyat yang baik akan berdampak pada pertumbuhan pohon selanjutnya. Baiknya 
kondisi kesehatan hutan juga akan memberikan kontribusi terhadap tujuan pengelolaan hutan

Dengan sehatnya hutan repong damar, maka pengelola hutan rakyat akan mendapatkan keuntungan yang besar dari setiap penjualan getah. Selain getah damar, pohon damar juga dapat dimanfaatkan dengan menebang pohon yang sudah berusia tua atau yang sudah roboh dengan tujuan yang jelas seperti untuk membuat rumah. Permintaan pasokan kayu damar tidak lepas dari kualitas kayu yang dihasilkan oleh pohon damar. Masyarakat setempat masih menjaga adat yang ada.

\section{KESIMPULAN}

Hasil penelitian menunjukkan bahwa nilai indikator produktivitas melalui parameter LBDs pada masing- masing klaster plot adalah 0,$280 ; 0,200 ; 0,280 ; 0,260 ; 0,400$. Tingkat produktivitas di repong damar tersebut tergolong sedang. Sedangkan nilai status kondisi kesehatan repong damar Pekon Pahmungan, Kecamatan Pesisir Tengah, Kabupaten Pesisir Barat adalah berada pada klaster plot 5 dengan kondisi kesehatan hutan yang baik, kategori sedang dua klaster plot yaitu klaster plot 1 dan 3 .

\section{DAFTAR PUSTAKA}

Apriyanto, D.,Hardjanto dan Hero, Y. 2016. Peningkatan Peran Hutan Rakyat Dalam Mendukung Ketahanan Pangan Dan Penanggulangan Kemiskinan rakyat yaitu produksi (Rochmah dkk., 2021).

Mereka meyakini bahwa menebang pohon damar merupakan suatu sikap perlawanan terhadap nenek moyang. Tingkat kesehatan hutan Repong Damar dapat memberikan gambaran bahwa hutan rakyat yang ditanam pola agroforestri memiliki keunggulan. Di antaranya yaitu daya tahan terhadap serangan hama penyakit yang kuat dan secara tidak langsung memberikan keuntungan ganda bagi pertumbuhan pohon sehingga tumbuh lebih baik (Diniyati dkk., 2004).

Sedangkan kategori jelek berada pada klaser plot 3 dan 4. Pengambilan keputusan yang tepat dalam pengelolaan hutan rakyat dapat dilakukan dengan cara penilaian status kondisi kesehatan hutan menggunakan indikator produktivitas dengan parameter pengukuran luas bidang dasar (LBDs) yang dapat menyebabkan melambatnya laju pertumbuhan pohon damar. Dengan demikian, status kondisi repong damar Pekon Pahmungan, Kecamatan Pesisir Tengah, Kabupaten Pesisir Barat rata-rata berada pada kondisi yang sedang.

(Studi Kasus Di Kecamatan Nanggung, Kabupaten Bogor), Jurnal Silvikultur Tropika; 7(3) : 165-173.

Cline, S.P. 1995. FHM: Environmental Monitoring and Assesment Program 
Washington D.C. (US): U.S Environmental Protection Agency, Office of Research and Development.

Cusson, A. 2013. Cat's eye forests: The Krui Damar Gardens. FAO, Rome. ftp://ftp.fao.org [diakses pada 23 Oktober 2020].

Dewi, B.S., Harianto, S.P., Bintoro, A., Iswandaru, D., Pramana, R. Dan Riyanto, D. 2017. Fauna Agroforest.Seminar Nasional BKS PTN Wilayah Barat Bidang

Pertanian. [Prosiding]. Halaman 903-909. Diakses pada 24 September 2020.

De Foresta, H., Kusworo, A., Michon, G. dan Djatmiko, W.A. 2000. Ketikakebun berupa hutan: Agroforest Khas Indonesia Sebuah sumbangan masyarakat. Buku. SMT Grafika Desa Putera. Jakarta. 241 hlm.

Diniyati, D., Yuliani, S. E., Suryano dan Badrunasar, A. 2004. Pola tanam hutan rakyat di jawa dalam rangka meningkatkan pendapatan petani. Jurnal Al-Basia. 1(4): 1-14.

Handoko, A., Rizki, K.T., Yanuar, S., Dwitantian, H.B., Dita, T., Putri, O.,Prima, Y. dan Nurlaela, A.H. 2015. Evaluasi kesehatan pohon di kawasan asrama internasinal ipb.https://rizkikurniatohir.files.wordpre ss com/2016/03/ fhm.pdf. Diakses pada 27 Juni 2020.

Harianto, S.P., Dewi, B.S. dan Rusita. 2016.

Buku. Repong Damar. Lembaga Penelitian Universitas Lampung. Graha Ilmu. Yogyakarta.

Herawati, T. 2012. Perjalanan multiabad repong damar: kajian aspek tata guna lahan. Puslitbang peningkatan produktivitas hutan-Badan. Litbang Kementerian Kehutanan. Lampung.
Kuswandi, R. 2017. Model pertumbuhan tegakan hutan alam bekas tebangan dengan sistem tebang pilih di papua, Jurnal Pemuliaan Tanaman Hutan; 11(1) : 45-55.

Lensari, D. Yuningsih, L. 2017. Kontribusi agroforesti repong damar terhadap pendapatan masyarakat. Sylva. 6(1):30 34.

Nainggolan, V. 2011. Analisis Populasi Jenis Primata di Repong Damar Pekon Pahmungan Kecamatan Pesisir Tengah Krui Lampung Barat. Skripsi. Universitas Lampung. Bandar Lampung. $\quad 56 \mathrm{hlm}$.

Nuhamara, S.T., Kasno, dan Irawan, U.S. 2001. Assessment on Damage Indicators in Forest Health Monitoring to Monitor the Sustainability of Indonesian Tropical Rain Forest. Dalam: Forest Health Monitoring to Monitor The Sustainability of Indonesian Tropical Rain Forest. Volume II. ITTO, Japan and SEAMEO-BIOTROP. Bogor

Oktaviyani, E.S., Indriyanto dan Surnayanti. 2017. Identifikasi Jenis Tanaman Hutan Rakyat Dan Pemeliharaannya Di Hutan Rakyat Desa Kelungu Kecamatan Kotaagung Kabupaten Tanggamus, Jurnal Sylva Lestari; 5(2) :63-77.

Philip MS. 1994. Measuring Trees and Forest. Wallingford: CAB Int. Health Monitoring Di Kph Balapulang, Ecogreen; 4(1) : 9-15.

Pratiwi dan Safe'i, R. 2018. Penilaian Vitalitas Pohon Jati Dengan Forest Health Monitoring Di Kph Balapulang, Ecogreen; 4(1) : 9-15.

Putra, E. I. 2004. Pengembangan Metode Penilaian Kesehatan Hutan Alam Produksi. Tesis. Institut Pertanian Bogor, Bogor, P.63. 
Riyanto HD dan Pamungkas BP. 2010. Model Pertumbuhan Tegakan Hutan Tanaman Sengon Untuk Pengelolaan Hutan, Jurnal Tekno Hutan Tanaman; 3(3):113- 120.

Rochmah, S.F., Safe'i, R., Bintoro, A., Kaskoyo, H. and Rahmat, A. 2021. The effect of forest health on social conditions of the community. IOP conference Series: Earth and Environmental Science. $8 p$.

Safe'i, R. Hardjanto, Supriyanto dan Sundawati, L. 2013. Pengembangan Metode Penilaian Kesehatan Hutan Rakyat Sengon (Falcataria moluccana (Miq.) Barneby \& J.W. Grimes), Jurnal Penelitian Hutan Tanaman; 12(3) : 175-187.

Safe'i, R. 2015. Kajian Kesehatan hutan dalam Pengelolaan Hutan Rakyat di Provinsi Lampung. disertasi. Institut Pertanian Bogor, Bogor, $101 \mathrm{hlm}$.

Safe'i, R. 2017. Pengembangan Metode Penilaian Kesehatan Hutan Rakyat Sengon(Paraserianthes falcataria). Makalah diberikan pada Seminar Doktor Fakultas Pertanian UNILA. 9 Maret. Bandar Lampung.

Safe'i, R. dan Tsani, M. K. 2016. Kesehatan Hutan: Penilaian Kesehatan Hutan Menggunakan Teknik Forest Health Monitoring. Buku. Lembaga Penelitian Dan Pengabdian Kepada Masyarakat Universitas Lampung, Bandar Lampung, P.102.

Safe'i, R., dan Tsani, K. M. 2017. Penyuluhan Program Kesehatan Hutan Rakyat Di Desa Tanjung Kerta Kecamatan Kedondong Kabupaten Pesawaran, Jurnal Pengabdian kepada Masyarakat; 1(1): 1-3

Safe'i, R., Erly, H., Wulandari, C. Dan
Kaskoyo, H. 2018. Analisi Keanekaragama Jenis Pohon Sebagai Salah Satu Indikato Kesehatan Hutan Konservasi, Jurnal Perennial; 14(2): 32-36.

Safe'i, R., Wulandari, C. dan Kaskoyo, H. 2019. Analisis Kesehatan Hutan Dalam Pengelolaan Hutan Rakyat Pola Tanam Agroforestri di Wilayah Kabupaten Lampung Timur, ANR Conserence Series 02, Talenta Publisher, Universitas Sumatera Utara. pp.97-103.

Safe'i, R., Wulandari, C. dan Kaskoyo, H. 2019. Penilaian Kesehatan Hutan Pada Berbagai Tipe Hutan Di Provinsi Lampung, Jurnal Sylva Lestari; 7(1) : 95-109.

Safe'i, R., Latumahina, F.S., Suroso, E. And Warsono. 2020. Identification of durian tree health (Durio zibethinus) in the prospective nusantara garden wan abdul rachman lampung indonesia. Journal of Plant Cell Biotechnology and Molecular Biology. 21(41\&42): 103-110.

Safe'i, R., Darmawan, A., Kaskoyo, H. And Rezinda, G.F.C. 2020. Analysis of changes in forest health status values in conservation forest (case study: plant and anima collection blocks in wan abdul rachman forest park (tahura war)). Journal of Physics: Conference Series. $11 p$.

Safe'i, R., Latumahina, F.S., Dewi, B.S., and Ardiansyah, F. 2021. Journal of Biodiversitas. 22(4). 2072-2077.

Safe'i, R., Sari, N.R., Iswandaru, D., Latumahina, F.S., Taskirawati, I. and Kaskoyo, H. 2021. Biodiversity and site quality as indicators of mangrove forest health pasir sakti, indonesia. Journal of Annals of R.S.C.B. 25(2): 4400-4410.

Sahid. 2009. Penafsiran Luas Bidang Dasar Tegakan Pinus Merkusii Menggunakan 
Foto Udara Di Kesatuan Pemangkuan Hutan (Kph) Kedu Perum Perhutani Unit 1 Jawa Tengah, Forum Geografi; 23(2) : 112-122.

Sugiyono. 2010. Metode Penelitian Pendidikan Pendekatan Kuantitatif, Kualitatif, Dan R\&D. Buku. Alfabeta,
Bandung.

USDA. 1999. Forest Health Monitoring Field Methods Guide International. Buku. National Forest Health Program, Washington DC, p.230. 
DOI:10.30598/jhppk.2021.5.1.14

ISSN ONLINE:2621-8798

Page 26 
DOI:10.30598/jhppk.2021.5.1.14

ISSN ONLINE:2621-8798

Page 27 